OPTIMUM. ECONOMIC STUDIES NR 2 (92) 2018

\title{
Dr Paweł DZIEKAŃSKI
}

Instytut Prawa, Ekonomii i Administracji, Uniwersytet Jana Kochanowskiego w Kielcach e-mail: pdziekan@interia.eu

DOI: 10.15290/oes.2018.02.92.03

\section{SYTUACJA FINANSOWA A ROZWÓJ ZRÓWNOWAŻONY POWIATÓW POLSKI WSCHODNIEJ}

\begin{abstract}
Streszczenie
Celem opracowania była ocena poziomu zróżnicowania sytuacji finansowej i rozwoju powiatów Polski Wschodniej w kontekście rozwoju za pomocą miary syntetycznej. Przeprowadzone analizy dokonano w układzie 101 powiatów Polski Wschodniej. Jako materiał źródłowy wykorzystano dane z Bazy Danych Lokalnych Głównego Urzędu Statystycznego (dla 2010, 2012 i 2016). Rozkład miary syntetycznej sytuacji finansowej i rozwoju powiatów Polski Wschodniej jest przestrzennie spolaryzowany. Najlepszymi jednostkami okazały m. Krosno, m. Rzeszów, m. Lublin, m. Kielce czy powiaty łęczyński, węgorzewski, wysokomazowiecki, skarżyski, stalowowolski. Najsłabszymi - powiaty przemyski, chełmski, zamojski. Wśród czynników, które utrzymują to zróżnicowanie, wymienia się m.in. środki finansowe, zasoby środowiska, infrastruktury, potencjał gospodarczy. Proces działania jednostki odbywa się w nich współzależnie i powinien być rozpatrywany łącznie.
\end{abstract}

Słowa kluczowe: sytuacja finansowa, rozwój zrównoważony, powiat, Polska Wschodnia

JEL: H41, H7, H72, H83

\section{FINANCIAL SITUATION OF A SUSTAINABLE DEVELOPMENT OF POLISH EASTERN OF POVIATS}

\begin{abstract}
Summary
The aim of the study is assessed the level of diversification of the financial situation of counties of Eastern Poland in the context of development by means of a synthetic measure. The analyzes were carried out in the system of 101 poviats of Eastern Poland. The source material was data from the Local Data Base of the Central Statistical Office (for 2010, 2012 and 2016). The distribution of the measure of the synthetic financial situation and development of the poviats of Eastern Poland is spatially polarized. The best units were those of Krosno, Rzeszów, Lublin, Kielce and łęczyński, węgorzewski, wysokomazowiecki, skarżyski, stalowowolski. The weakest poviats are przemyski, chełmski and zamojski. Among factors that maintain this diversity, mention is made of financial resources, environmental resources, infrastructure, economic potential. The operation of the unit takes place in them interdependent and should be considered together.
\end{abstract}

Key words: financial situation, sustainable development, poviat, Eastern Poland 


\section{Wstęp}

Jednostki samorządu terytorialnego (JST), (gminy, powiaty i województwa) działają i rozwijają się w coraz bardziej złożonym otoczeniu, które stanowi miejsce koncentracji aktywności gospodarczej oraz jest kreatorem rozwoju lokalnego i regionalnego. Charakteryzują się one autonomią w podejmowaniu decyzji, a ich działania są skierowane na wszystkie typy zasobów, tj. finansowych, ludzkich, rzeczowych i informacyjnych. W działaniu jednostek samorządu terytorialnego specjalnego znaczenia nabiera zarządzanie środkami finansowymi, które oddziałuje na sytuację ekonomiczną samorządu [Dworakowska, 2013, s. 31-39].

Realizowana przez powiat gospodarka finansowa determinuje rozwój innych dziedzin działania samorządu. Jest ona źródłem informacji o potencjale rozwoju gospodarczego jednostki [Wojciechowski, 2012, s. 234-235]. Wieloaspektowe obszary wpływu zarządzania finansami powinny być uwzględniane w analizie funkcjonowania powiatów [Kozłowski, 2012, s. 52].

Jednostki samorządu terytorialnego jako podmioty prowadzące własną gospodarkę finansową stają przed wieloma złożonymi problemami, które wynikają ze zmienności ich otoczenia. Gospodarowanie finansami powiatu jest procesem decyzyjnym, dla którego istotnym elementem staje się informacja. Podejmowane decyzje, aby były racjonalne, nie mogą być podejmowane w sposób intuicyjny. Powinny opierać się na wiarygodnych i odpowiednio przetworzonych informacjach [Dylewski, Filipiak i Gorzałczyńska-Koczkodaj, 2004, s. 7; Wysocki, 2010; Jajuga, 1993].

Zagadnienie rozwoju społeczno-gospodarczego to zjawisko o charakterze wielokryteriowym. Związane jest zarówno $\mathrm{z}$ aspektem ekonomicznym, jak i demograficznym, przyrodniczym i innymi. Rozwój, pozytywne zmiany ilościowe, jakościowe i strukturalne $\mathrm{w}$ gospodarce regionu, w głównej mierze warunkowany jest położeniem geograficznym [Szymla, 2000]. Nie bez znaczenia są również działania administracyjne mające na celu likwidowanie dysproporcji występujących pomiędzy regionami.

\section{Cel, materiał i metoda badawcza}

Celem artykułu była ocena poziomu zróżnicowania sytuacji finansowej JST w kontekście rozwoju. Wskazane procesy to zjawiska złożone. Odpowiednim sposobem ich badania wydało się być stworzenie miary syntetycznej. Prowadzona analiza obejmowała porównanie sytuacji w 2010, 2012 i 2016 roku. Podstawę informacyjną badań stanowiły dane pochodzące $\mathrm{z}$ bazy danych publikowanych przez GUS (Bank Danych Lokalnych). Przedmiotem analizy było 101 powiatów (ziemskich i grodzkich) Polski Wschodniej.

Wybrany zestaw zmiennych zaproponowany $\mathrm{w}$ analizie powiatów obejmuje cechy, określające ich potencjał finansowy, gospodarczy, infrastrukturalny (tabela 1). Od ilości środków finansowych i ich prawidłowej alokacji zależy reali- 
TABELA 1

\section{Zmienne opisujące rozwój powiatów}

\begin{tabular}{|c|c|c|}
\hline $\begin{array}{l}\text { Aspekt finansowy } \\
(\text { per capita) }\end{array}$ & Aspekt gospodarczy & Aspekt infrastrukturalny \\
\hline F1. Dochody z PIT (s) & $\begin{array}{l}\text { G1. \% ludności korzystającej } \\
\text { z wodociągu (s) }\end{array}$ & I1. Zasoby mieszkaniowe (s) \\
\hline F2. Dochody z CIT (s) & $\begin{array}{l}\text { G2. \% ludności korzystającej } \\
\text { z kanalizacji (s) }\end{array}$ & $\begin{array}{l}\text { I2. Sieć rozdzielcza } \\
\text { wodociągowa } \mathrm{km}^{2} \text { (s) }\end{array}$ \\
\hline F3. Subwencja (d) & $\begin{array}{l}\text { G3. \% ludności korzystającej } \\
\text { z sieci gazowej (s) }\end{array}$ & $\begin{array}{l}\text { I3. Sieć rozdzielcza } \\
\text { kanalizacyjna km² (s) }\end{array}$ \\
\hline $\begin{array}{l}\text { F4. Nadwyżka operacyj- } \\
\text { na (s) }\end{array}$ & $\begin{array}{l}\text { G4. Zmiana liczby ludności } \\
\text { na } 1000 \text { mieszkańców (d) }\end{array}$ & $\begin{array}{l}\text { I4. Sieć rozdzielcza } \\
\text { gazowa } \mathrm{km}^{2}(\mathrm{~s})\end{array}$ \\
\hline F5. Wydatki inwestycyjne (s) & $\begin{array}{l}\text { G5. Podmioty wpisane do } \\
\text { rejestru na } 1000 \\
\text { ludności (s) }\end{array}$ & $\begin{array}{l}\text { I5. Ludność na } 1 \text { placówkę } \\
\text { biblioteczną (s) }\end{array}$ \\
\hline F6. Wydatki na zdrowie (s) & $\begin{array}{l}\text { G6. Os. fizyczne prowadzące } \\
\text { działalność gospodarczą } \\
\text { na } 1000 \text { ludności (s) }\end{array}$ & $\begin{array}{l}\text { I6. Ludność na } 1 \text { aptekę } \\
\text { ogólnodostępną (s) }\end{array}$ \\
\hline $\begin{array}{l}\text { F7. Wydatki na bez- } \\
\text { pieczeństwo (s) }\end{array}$ & $\begin{array}{l}\text { G7. Bezrobocie rejestrowane } \\
\text { ogółem (d) }\end{array}$ & $\begin{array}{l}\text { I7. Przychodnie podległe } \\
\text { samorządom (s) }\end{array}$ \\
\hline $\begin{array}{l}\text { F8. Wydatki na obsługę } \\
\text { długu (d) }\end{array}$ & $\begin{array}{l}\text { G8. pracujący na } 1000 \\
\text { ludności ogółem (s) }\end{array}$ & $\begin{array}{l}\text { I8. Powierzchnia gruntów } \\
\text { leśnych (\% ogólnej } \\
\text { powierzchni; s) } \\
\text { I9. Drogi powiatowe o na- } \\
\text { wierzchni twardej (km; s) }\end{array}$ \\
\hline
\end{tabular}

s - stymulanta; d - destymulanta.

Źródło: opracowanie własne.

zacja m.in. polityki inwestycyjnej, czy stymulowanie rozwoju społeczno-ekonomicznego. Zjawisko rozwoju społeczno-gospodarczego zostało dodatkowo opisane przez warunki demograficzne, jak charakteryzujące stan środowiska przyrodniczego [Grabiński, Wydymus i Zeliaś, 1983].

Dobór zmiennych do badania dokonuje się opierając się na kryteriach merytorycznych (uwzględniając zasadę maksymalny zasób informacji przy minimalnej liczbie cech) lub statystycznych (najczęściej przy użyciu współczynnika zmienności czy analizy odwróconej macierzy korelacji). Zmienną objaśniającą nie może być bowiem zmienna, której poszczególne obserwacje nie różnią się między sobą lub różnią się niewiele (zmienna stała lub quasi-stała). Dwie cechy nadmiernie skorelowane są nośnikami podobnej informacji. W przypadku macierzy odwrotnej korelacji wartość ich elementów diagonalnych powyżej 10 eliminuje ją ze zbioru zmiennych. Procedurę powtarza się do momentu osiągnięcia stabilności macierzy [Malina, 2004, s. 96-97]. Należy pamiętać także, że zbyt liczny zbiór cech utrudnia lub uniemożliwia poprawną klasyfikację, to samo jednak można powiedzieć, gdy zbiór jest zbyt mały w sensie reprezentatywności [Zeliaś, 2002]. 
W kolejnym etapie badania dokonano normalizacji zmiennych za pomocą metody unitaryzacji zerowej, wykorzystując formułę:

dla stymulanty (1),

$$
z_{i j}=\frac{x_{i j}-\min _{i} x_{i}}{\max _{i} x_{i}-\min _{i} x_{i}} ;
$$

dla destymulanty (2),

$$
z_{i j}=\frac{\max _{i} x_{i}-x_{i j}}{\max _{i} x_{i}-\min _{i} x_{i}},
$$

gdzie: $i=1,2, \ldots, N ; j=1,2, \ldots, p(N$ jest liczbą obiektów (powiatów), a $p-$ liczbą cech); - oznacza wartość zunitaryzowną cechy dla badanej jednostki, $x_{i j}$ - oznacza wartość j-tej cechy dla badanej jednostki, max - maksymalna wartość j-tej cechy, min - minimalna wartość j-tej cechy [Wysocki, 1996].

Kolejno wyznaczono wartość kompleksowej miary syntetycznej w oparciu od indywidualne wartości miar dla każdego aspektu zmiennych oddzielnie. Wyznaczono je w oparciu o metodę odległości w rzeczywistej przestrzeni z metryką euklidesową zgodnie ze wzorem [Dziekański, 2015, s. 261-279; Dziekański, 2016; Dziekański, 2017; Mioduchowska-Jaroszewicz, 2013, s. 127-140]:

$$
O E_{i t}=\sqrt{\frac{\sum_{j=1}^{p}\left(1-z_{i j t}\right)^{2}}{p} .}
$$

Miara syntetyczna (3) pozwala na zmierzenie sprowadzonej do przedziału [0;1] odległości $\mathrm{w}$ rzeczywistej przestrzeni $\mathrm{z}$ metryką euklidesową $i$-tej gminy w roku $t$ od hipotetycznej gminy - wzorca, czyli takiej, która charakteryzowałby się maksymalną wartością każdej z badanych cech. Wartość miary równa 0 oznacza maksymalną pozytywną wartość badanej jednostki [Trojak, Tokarski, 2013].

Miara syntetyczna pozwoliła podzielić badany obszar powiatów na 4 grupy kwartylowe. Wielkość wskaźnika w pierwszej grupie kwartylowej oznacza jednostkę lepszą i odpowiednio czym grupa niższa, tym jednostki są słabsze. Zweryfikowano także zgodność uzyskanych wyników opierając się na współczynniku korelacji oraz dokonano oceny zróżnicowania grup na podstawie testów NIR oraz RIR Tukeya.

\section{Przestrzenne zróżnicowanie relacji sytuacji finansowej i rozwoju zrównoważonego powiatów w Polsce Wschodniej}

Samorząd terytorialny jako podmiot władzy publicznej wykonuje zadania publiczne niezastrzeżonych na rzecz innych podmiotów prawa publicz- 
nego. Konstytucyjna indywidualność samorządu terytorialnego przejawia się zarówno pod względem instytucjonalnym, jak i funkcjonalnym [Orzeczenie..., 1995; Oniszczuk, 2000, s. 212]. Jedną z podstawowych zasad powiatu jest samodzielne prowadzenie gospodarki finansowej na podstawie budżetu, który jest kluczową instytucją systemu finansowego.

Sytuacja finansowa powiatu jest ściśle skorelowana z poziomem rozwoju lokalnego, rozumianym jako kompleks ilościowych i jakościowych przeobrażeń na terenie danej jednostki, odnoszących się do poziomu życia mieszkańców oraz funkcjonowania podmiotów gospodarczych [Sobczyk, 2010, s. 125-136]. Przekłada się ona na dysproporcje w zakresie możliwości zaspokajania potrzeb lokalnych czy sposobu i jakości realizacji zadań publicznych. Źródła dochodowe powiatów są wyrazem ich samorządności finansowej. Muszą cechować się one wydajnością, aby powiaty mogły wykonywać przewidziane dla siebie zadania [Kopyściański, Rólczyński, 2014, s. 61-62].

Zdaniem Adamowicza rozwój lokalny jest wynikiem aktywności lokalnych podmiotów wykorzystujących dostępne im wewnętrzne i zewnętrzne zasoby. Przebieg tych procesów kształtowany jest przez ogólny system ekonomiczny i społeczny czy lokalną politykę prowadzoną przez władze lokalne [Adamowicz, 2003, s. 11]. Jednym z fundamentalnych kryteriów jest tzw. baza ekonomiczna wyrażona wielkością dochodów własnych. Im wyższe dochody własne w strukturze dochodów, tym większa jego samodzielność finansowa w projektowaniu i wykonywaniu postawionych przed nim zadań. Wyżej też ocenia się efekty pracy kierujących takimi jednostkami [Kachniarz, 2011].

Analiza pozwoliła podzielić gminy wiejskie na 4 grupy. Wartość wskaźnika wahała się w granicach w 2010 - 0,62 (najlepsza jednostka; powiat m. Krosno) do 0,83 (najsłabsza jednostka; powiat zamojski), w 2012 - 0,65 (powiat m. Lublin) do - 0,83 (powiat zamojski) w $2016-0,60$ (powiat m. Krosno) do 0,81 (powiat zamojski). W przypadku badanych jednostek w lepszej sytuacji były miasta na prawach powiatu. W 2010 roku najlepszymi jednostkami były powiat m. Krosno, m. Rzeszów oraz powiat łęczyński; w 2012 - powiat m. Lublin, m. Rzeszów, powiat węgorzewski; w 2016 - powiat m. Krosno, m. Lublin, powiat wysokomazowiecki. Najsłabszymi okazały się powiaty przemyski, chełmski, zamojski w 2010; przemyski, zamojski w 2012; chełmski, zamojski w 2016.

Rozkład miary syntetycznej sytuacji finansowej powiatów Polski Wschodniej jest przestrzennie spolaryzowany. Na sytuacje finansową wpływy charakter gospodarczy regionu, położenie względem silnych jednostek miejskich, dochody z PIT i CIT czy wydatki inwestycyjne. Między grupami można zaobserwować przesunięcia w czasie i między grupami (tabela 2).

Rozwój powiatu (gminy czy województwa) w dużej mierze uzależniony jest od sytuacji finansowej jednostki. Zasoby finansowe są podstawą działania jednostki oraz warunkiem realizacji przez nią zadań ustawowych (związanych m.in. z rozwiązywaniem problemów społecznych, podejmowaniem działań związanych z potrzebami mieszkańców) [Borodo, 2007, s. 200]. 
TABELA 2

Klasyfikacja powiatów Polski Wschodniej wg miary syntetycznej sytuacji finansowej w latach 2010, 2012, 2016

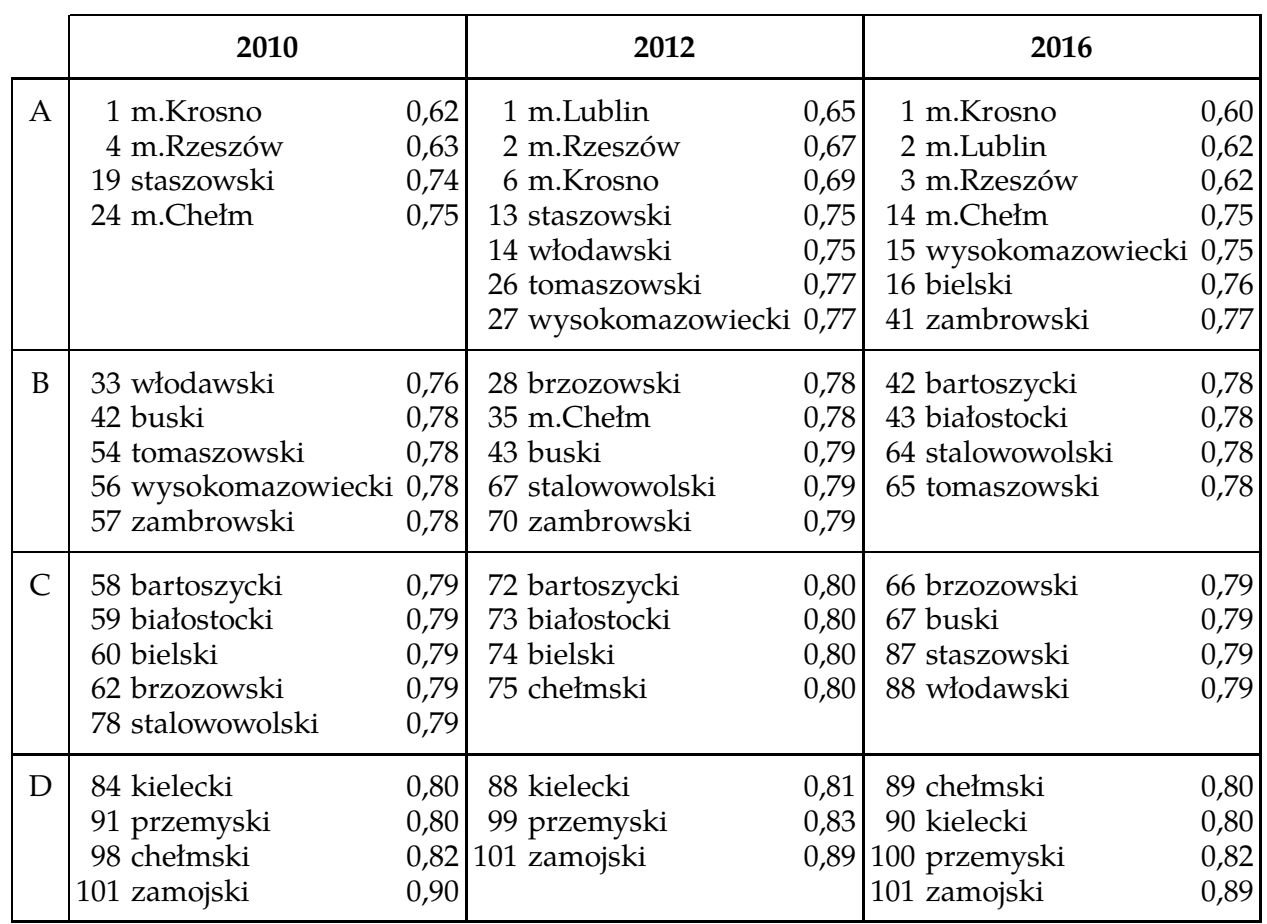

miejsce $\mathrm{w}$ rankingu / powiat / miara syntetyczna; miara syntetyczna dla miast na prawach powiatu oraz powiatów ziemskich były liczone oddzielnie; następnie ujęte $\mathrm{w}$ jedną tabele

Źródło: opracowanie własne na podstawie danych BDL GUS.

Olbrzymie znaczenie dla rozwoju ma wewnętrzny potencjał jednostki, na który składają się uwarunkowania przyrodnicze, takie jak ukształtowanie terenu, położenie $\mathrm{w}$ obrębie obszarów chronionych. Powoduje on zróżnicowanie $\mathrm{w}$ poziomie rozwoju społeczno-gospodarczego jednostek samorządu terytorialnego [Heffner, 2002]. Renta położenia stanowi występowanie pewnych czynników na badanym obszarze oraz odległość jednostki od układu lokalnego czy regionalnego. Szczególnie ważne jest położenie wobec sieci osadniczej i komunikacyjnej. Jest ona zestawem mniej lub bardziej wymiernych korzyści płynących $\mathrm{z}$ umiejscowienia danej jednostki samorządu terytorialnego w przestrzeni społecznej i gospodarczej oraz geograficznej. Jest swego rodzaju premią atrakcyjnej lokalizacji [Ossowska, Poczta, 2009; Ossowska, 2013].

Charakterystyczną cechą konstrukcji przestrzennej gospodarki są dysproporcje w poziomie rozwoju gospodarczego powiatów, których czynnikiem sprawczym mogą być sytuacja finansowa, aspekt infrastruktury czy zasoby 
TABELA 3

Klasyfikacja powiatów Polski Wschodniej wg miary syntetycznej rozwoju w latach 2010, 2012, 2016

\begin{tabular}{|c|c|c|c|c|c|c|}
\hline \multirow{2}{*}{$\mathrm{A}$} & \multicolumn{2}{|l|}{2010} & \multicolumn{2}{|l|}{2012} & \multicolumn{2}{|l|}{2016} \\
\hline & $1 \mathrm{~m}$. Kielce & 0,48 & $1 \mathrm{~m}$.Kielce & 0,50 & $1 \mathrm{~m}$.Kielce & 0,48 \\
\hline & $3 \mathrm{~m}$. Lublin & 0,51 & 2 m.Lublin & 0,50 & 2 m.Lublin & 0,48 \\
\hline & 5 m.Krosno & 0,53 & 3 m.Rzeszów & 0,51 & 3 m.Rzeszów & 0,48 \\
\hline & 6 m.Rzeszów & 0,55 & 6 m.Krosno & 0,56 & 5 m.Krosno & 0,52 \\
\hline & 10 m.Chełm & 0,62 & 11 m.Chełm & 0,64 & 10 m.Chełm & 0,61 \\
\hline & 20 stalowowolski & 0,70 & 16 stalowowolski & 0,68 & 17 stalowowolski & 0,66 \\
\hline & 27 staszowski & 0,72 & 27 Powiat staszowski & 0,71 & 29 kielecki & 0,70 \\
\hline \multirow[t]{5}{*}{ B } & 32 białostocki & 0,74 & 28 buski & 0,72 & 31 białostocki & 0,71 \\
\hline & 33 buski & 0,74 & 34 białostocki & 0,73 & 32 buski & 0,71 \\
\hline & 35 kielecki & 0,74 & 35 kielecki & 0,73 & 48 staszowski & 0,72 \\
\hline & 60 zambrowski & 0,76 & 57 tomaszowski & 0,75 & & \\
\hline & & & 59 zambrowski & 0,75 & & \\
\hline \multirow[t]{5}{*}{$\mathrm{C}$} & 62 bielski & 0,77 & 60 bielski & 0,76 & 56 bielski & 0,74 \\
\hline & 71 tomaszowski & 0,77 & 70 wysokomazowiecki & 0,76 & 66 zambrowski & 0,74 \\
\hline & 73 wysokomazowiecki & 0,77 & 72 bartoszycki & 0,77 & 67 bartoszycki & 0,75 \\
\hline & 74 bartoszycki & 0,78 & 73 brzozowski & 0,77 & 75 tomaszowski & 0,75 \\
\hline & & & 82 włodawski & 0,77 & 77 wysokomazowiecki & 0,75 \\
\hline \multirow[t]{5}{*}{$\mathrm{D}$} & 83 brzozowski & 0,79 & 87 przemyski & 0,78 & 78 brzozowski & 0,76 \\
\hline & 89 włodawski & 0,79 & 97 chełmski & 0,81 & 84 przemyski & 0,76 \\
\hline & 92 przemyski & 0,80 & 101 zamojski & 0,83 & 89 włodawski & 0,77 \\
\hline & 98 chełmski & 0,83 & & & 99 chełmski & 0,80 \\
\hline & 101 zamojski & 0,83 & & & 101 zamojski & 0,81 \\
\hline
\end{tabular}

miejsce $\mathrm{w}$ rankingu / powiat / miara syntetyczna; miara syntetyczna dla miast na prawach powiatu oraz powiatów ziemskich były liczone oddzielnie; następnie ujęte $\mathrm{w}$ jedną tabele

Źródło: opracowanie własne na podstawie danych BDL GUS.

majątkowe (kapitałowe), zasoby środowiska przyrodniczego oraz zasoby demograficzne, które stwarzają korzystne warunki dla procesów zachodzących $\mathrm{w}$ regionie.

Niska wartość miary syntetycznej, wskazuje na słaby poziom rozwoju powiatów. Wartość wskaźnika wahała się w granicach od 0,48 (najlepsza jednostka; powiat M. Kielce; wysoko znalazły się powiaty rzeszowski i skarżyski - 0,69) do 0,83 (najsłabsza jednostka; powiat zamojski) w 2010 roku; 0,50 (powiat m. Kielce; powiat skarżyski i stalowowolski - 0,68) do 0,83 (powiat zamojski) w 2012 roku; 0,48 (powiat m. Kielce; powiaty skarżyski i rzeszowski - 0,66) do 0,81 (powiat zamojski) w 2016 roku (tabela 3). Na wzrost poziomu rozwoju gospodarczego powiatów miały wpływ pozytywne zmiany w zakresie potencjału gospodarczego i infrastruktury czy sytuacji finansowej.

Ocenę poziomu zróżnicowania miary syntetycznej sytuacji finansowej prezentuje tabela 4 . Średnia wartość miary syntetycznej wyniosła 0,77 i 0,78. W badanym okresie odchylenie standardowe nie zmieniło się i wyniosło 0,05. Nie- 
TABELA 4

Zróżnicowanie miary syntetycznej sytuacji finansowej powiatów Polski Wschodniej w latach 2010, 2012, 2016

\begin{tabular}{|l|c|c|c|c|c|c|}
\hline \multirow{2}{*}{ Wyszczególnienie } & \multicolumn{3}{|c|}{$\begin{array}{c}\text { Miara syntetyczna } \\
\text { sytuacji finansowej }\end{array}$} & \multicolumn{3}{c|}{$\begin{array}{c}\text { Miara syntetyczna } \\
\text { rozwoju }\end{array}$} \\
\cline { 2 - 7 } & $\mathbf{2 0 1 0}$ & $\mathbf{2 0 1 2}$ & $\mathbf{2 0 1 6}$ & $\mathbf{2 0 1 0}$ & $\mathbf{2 0 1 2}$ & $\mathbf{2 0 1 6}$ \\
\hline Średnia & 0,77 & 0,78 & 0,77 & 0,73 & 0,73 & 0,71 \\
Odchylenie standardowe & 0,05 & 0,04 & 0,05 & 0,08 & 0,07 & 0,07 \\
Współczynnik zmienności & 0,06 & 0,05 & 0,06 & 0,10 & 0,10 & 0,10 \\
Min & 0,62 & 0,65 & 0,60 & 0,48 & 0,5 & 0,48 \\
Max & 0,90 & 0,89 & 0,89 & 0,83 & 0,83 & 0,81 \\
Rozstęp & 0,28 & 0,24 & 0,29 & 0,35 & 0,33 & 0,33 \\
Skośność & $-1,34$ & $-1,21$ & $-1,75$ & $-1,69$ & $-1,68$ & $-1,63$ \\
\hline
\end{tabular}

Źródło: opracowanie własne na podstawie danych BDL GUS.

wielkie zróżnicowanie badanych jednostek potwierdza także wartość rozstępu, która była w 2016 roku w relacji do 2010 roku wyższa o 0,01 $(0,29-0,28)$. Na niewielkie zmiany wskazuje także współczynnik zmienności, który wyniósł 0,06. Interpretować to można jako stałość sytuacji finansowej.

Oceniająca poziom zróżnicowania miary syntetycznej rozwoju w 2016 roku w stosunku do 2010 wskazuje stałość zróżnicowania wg odchylenia standardowego $(0,08-0,07)$, potwierdza to także wartość rozstępu, która w 2016 r. była nieznacznie mniejsza niż w 2010 roku $(0,33-0,35)$. W badanym okresie współczynnik zmienności nie uległ zmianie $(0,1)$, (tabela 3 ).

W tabeli 5 obserwujemy dodatnią współzależność pomiędzy miarą sytuacji finansowej, infrastruktury, potencjału gospodarczego i rozwoju powiatów Polski Wschodniej. Syntetyczna miara sytuacji finansowej w relacji do rozwoju w 2016 roku w stosunku do 2012 roku wzrosła (współczynnik korelacji Pearsona w tym okresie wynosił 0,797 do 0,847; co może wskazywać na dywergencję). Wartość miary korelacji wskazuje na dość stabilne przestrzenne zróżnicowanie sytuacji finansowej i rozwoju.

Analiza wykresu rozrzutu relacji miar syntetycznych sytuacji finansowej i rozwoju w latach 2010, 2012 i 2016 wskazuje na dobre dopasowanie linii regresji (oznaczonych linią ciągłą) do rzeczywistych danych. Płynie z nich wniosek, że miara podlegała w 2016 roku w relacji do 2012 roku dywergencji (współczynniki korelacji Pearsona w badanym przedziale czasu wyniósł w 2010 roku $\mathrm{r}=0,814$ / r2 = 0,662; w 2012 roku r = 0,797 / r2 = 0,634; $\mathrm{w} 2012$ roku r = 0,847 / r2 =0,718) (rysunek 1). Obserwujemy dodatnią współzależność pomiędzy miarą kondycji finansowej i poziomem rozwoju. Korzystniejszej ocenie sytuacji finansowej towarzyszy lepszy poziom rozwoju. Wyższemu poziomowi rozwoju niższy udział transferów środków publicznych. 
TABELA 5

Korelacja miar syntetycznych sytuacji finansowej i rozwoju powiatów Polski Wschodniej w latach 2010, 2012, 2016

\begin{tabular}{|c|c|c|c|c|}
\hline Wyszczególnienie & $\begin{array}{c}\text { Współczynnik } \\
\text { korelacji } \\
\text { gamma }\end{array}$ & $\begin{array}{c}\text { Współczynnik } \\
\text { korelacja } \\
\text { Spermana }\end{array}$ & $\begin{array}{c}\text { Współczynnik } \\
\text { korelacji tau } \\
\text { Kendalla }\end{array}$ & $\begin{array}{c}\text { Współczynnik } \\
\text { korelacji } \\
\text { Pearsona }\end{array}$ \\
\hline $\mathrm{S}_{\mathrm{f}} 2010-2012$ & 0,687 & 0,732 & 0,611 & 0,883 \\
$\mathrm{~S}_{\mathrm{f}} 2012-2016$ & 0,688 & 0,700 & 0,601 & 0,887 \\
$\mathrm{~S}_{\mathrm{r}} 2010-2012$ & 0,966 & 0,979 & 0,925 & 0,987 \\
$\mathrm{~S}_{\mathrm{r}} 2016-2016$ & 0,966 & 0,976 & 0,925 & 0,992 \\
\hline $\mathrm{S}_{\mathrm{r}} \mathrm{S}_{\mathrm{f}} 2010$ & 0,412 & 0,483 & 0,378 & 0,814 \\
$\mathrm{~S}_{\mathrm{r}} \mathrm{S}_{\mathrm{f}} 2012$ & 0,390 & 0,450 & 0,352 & 0,797 \\
$\mathrm{~S}_{\mathrm{r}} \mathrm{S}_{\mathrm{f}} 2016$ & 0,364 & 0,427 & 0,327 & 0,847 \\
$\mathrm{~S}_{\mathrm{r}} \mathrm{S}_{\mathrm{g}} 2010$ & 0,893 & 0,951 & 0,859 & 0,972 \\
$\mathrm{~S}_{\mathrm{r}} \mathrm{S}_{\mathrm{g}} 2012$ & 0,908 & 0,961 & 0,875 & 0,969 \\
$\mathrm{~S}_{\mathrm{r}} \mathrm{S}_{\mathrm{g}} 2016$ & 0,887 & 0,952 & 0,852 & 0,961 \\
$\mathrm{~S}_{\mathrm{r}} \mathrm{S}_{\mathrm{i}} 2010$ & 0,583 & 0,699 & 0,548 & 0,818 \\
$\mathrm{~S}_{\mathrm{r}} \mathrm{S}_{\mathrm{i}} 2012$ & 0,607 & 0,738 & 0,574 & 0,848 \\
$\mathrm{~S}_{\mathrm{r}} \mathrm{S}_{\mathrm{i}} 2016$ & 0,659 & 0,772 & 0,615 & 0,864 \\
\hline
\end{tabular}

$\mathrm{S}_{\mathrm{r}}$ miara syntetyczna rozwoju; $\mathrm{S}_{\mathrm{f}}$ miara syntetyczna sytuacji finansowej; $\mathrm{S}_{\mathrm{g}}$ miara syntetyczna aspekt gospodarki; $S_{i}$ miara syntetyczna aspekt infrastruktury; współczynnik korelacji istotny $\mathrm{z}$ p $<0,05$

Źródło: opracowanie własne na podstawie danych BDL GUS.

RYSUNEK 1

Zgodność wyników miar syntetycznych (sytuacja finansowa a rozwój) rok do roku z dopasowaniem linii regresji dla powiatów Polski Wschodniej w latach 2010, 2012, 2016
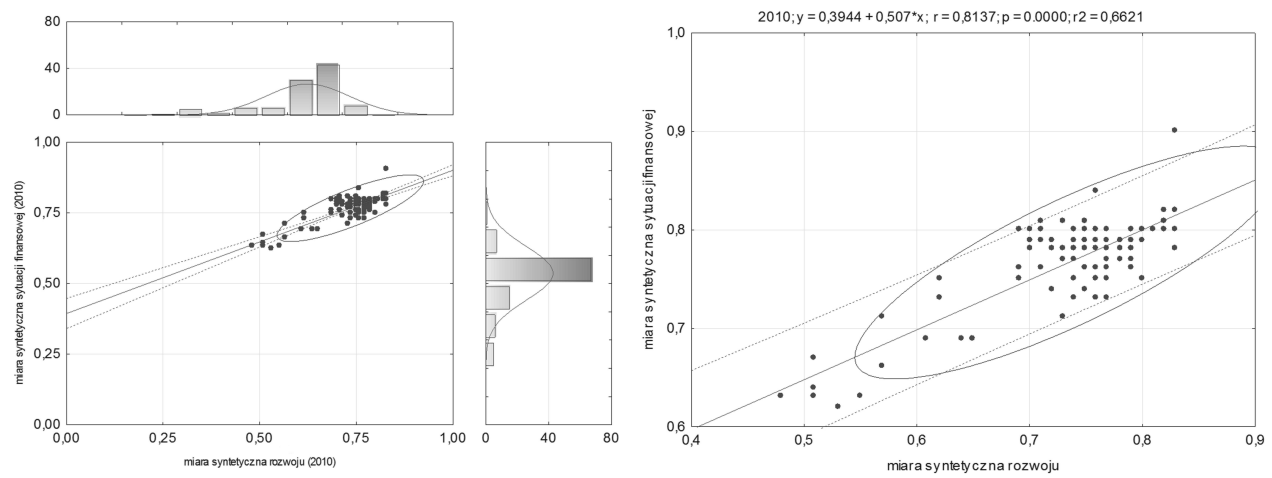

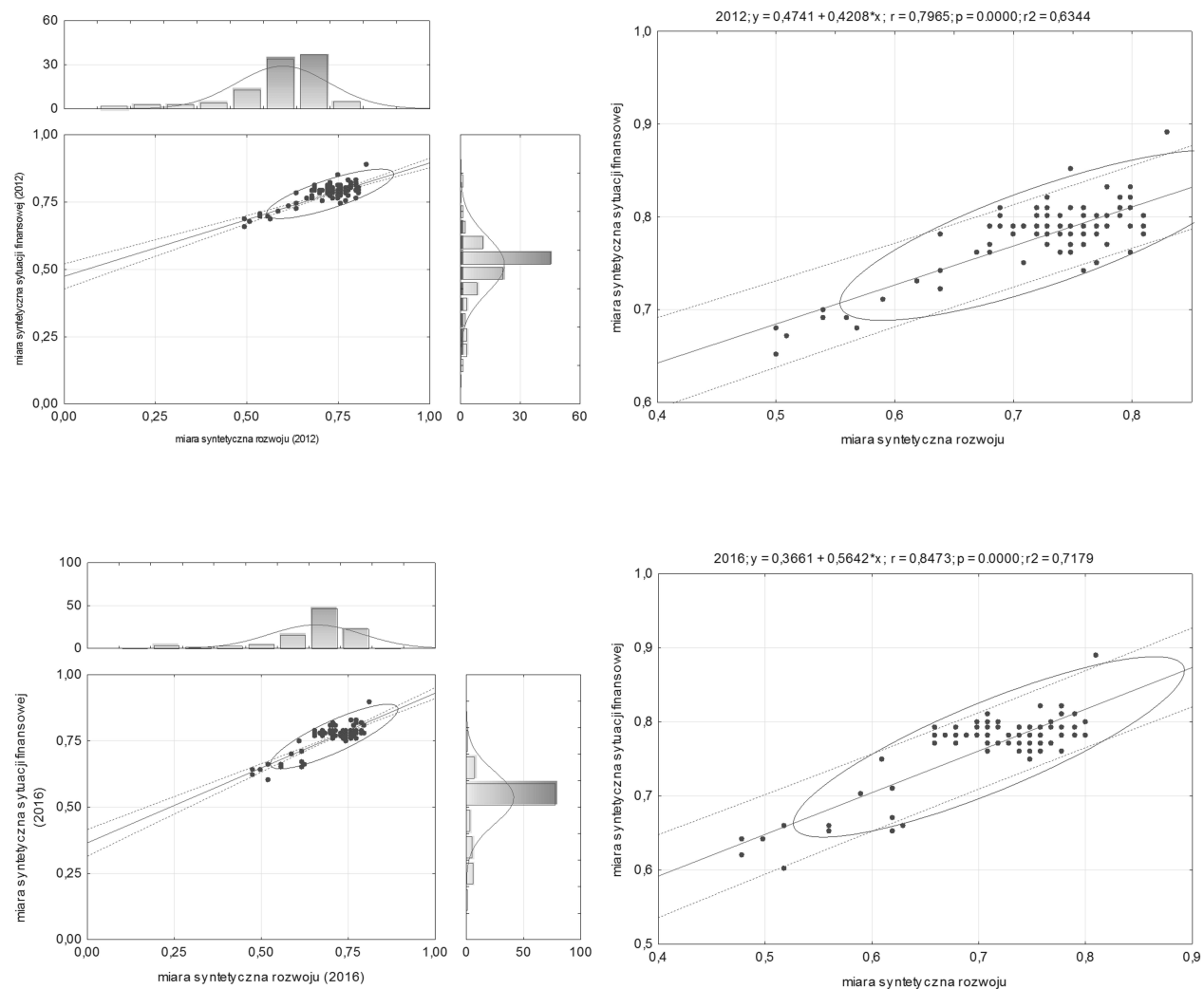

Źródło: opracowanie własne na podstawie danych BDL GUS.

Dla oceny, jak analizowane grupy różnią się między sobą wykorzystano testy Anova (test post hoc; program Statystyka). Ich wartości wskazują na względne podobieństwo wyodrębnionych grup pod względem relacji miary syntetycznej sytuacji finansowej i rozwoju. Średnie dla testów NIR, RIR różnią się istotnie dla relacji grupy A $(\mathrm{p}<0,05)$. Średnie dla pozostałych metod nie różnią się istotnie.

\section{Podsumowanie}

Samorząd terytorialny to bardzo istotny podmiot nie tylko społeczny, ale również gospodarczy w skali regionu. Znacząca część jego wydatków była przeznaczana na inwestycje, które przyczyniały się do rozwoju gospodarki [Efektywność..., 2012].

Dzięki ocenie sytuacji finansowej powiatu, jest możliwe kontrolowanie stanu i rozwoju gospodarki, a także analiza i diagnoza następstw finansowych działań i realizowanych zadan. 
TABELA 5

Zróżnicowanie rozwoju powiatów wg grup wartości miary syntetycznej sytuacji finansowej

\begin{tabular}{|c|c|c|c|c|c|c|c|c|c|}
\hline \multicolumn{4}{|c|}{ Test NIR } & \multicolumn{5}{c|}{ Test RIR Tukeya } \\
\hline 2010 & A & B & C & D & 2010 & A & B & C & D \\
\hline A & & $\mathbf{0 , 0 0}$ & $\mathbf{0 , 0 0}$ & $\mathbf{0 , 0 0}$ & A & & $\mathbf{0 , 0 0}$ & $\mathbf{0 , 0 0}$ & $\mathbf{0 , 0 0}$ \\
\hline B & $\mathbf{0 , 0 0}$ & & 0,93 & 0,42 & B & $\mathbf{0 , 0 0}$ & & 0,99 & 0,85 \\
\hline C & $\mathbf{0 , 0 0}$ & 0,93 & & 0,51 & C & $\mathbf{0 , 0 0}$ & 0,99 & & 0,91 \\
\hline D & $\mathbf{0 , 0 0}$ & 0,42 & 0,51 & & D & $\mathbf{0 , 0 0}$ & 0,85 & 0,91 & \\
\hline 2012 & A & B & C & D & 2012 & A & B & C & D \\
\hline A & & $\mathbf{0 , 0 0}$ & $\mathbf{0 , 0 0}$ & $\mathbf{0 , 0 0}$ & A & & $\mathbf{0 , 0 0}$ & $\mathbf{0 , 0 0}$ & $\mathbf{0 , 0 0}$ \\
\hline B & $\mathbf{0 , 0 0}$ & & 0,34 & 0,19 & B & $\mathbf{0 , 0 0}$ & & 0,78 & 0,55 \\
\hline C & $\mathbf{0 , 0 0}$ & 0,34 & & 0,74 & C & $\mathbf{0 , 0 0}$ & 0,78 & & 0,99 \\
\hline D & $\mathbf{0 , 0 0}$ & 0,19 & 0,74 & & D & $\mathbf{0 , 0 0}$ & 0,55 & 0,99 & \\
\hline 2016 & A & B & C & D & 2016 & A & B & C & D \\
\hline A & & $\mathbf{0 , 0 0}$ & $\mathbf{0 , 0 0}$ & $\mathbf{0 , 0 0}$ & A & & $\mathbf{0 , 0 2}$ & $\mathbf{0 , 0 0}$ & $\mathbf{0 , 0 0}$ \\
\hline B & $\mathbf{0 , 0 0}$ & & 0,17 & 0,68 & B & $\mathbf{0 , 0 2}$ & & 0,52 & 0,98 \\
\hline C & $\mathbf{0 , 0 0}$ & 0,17 & & 0,31 & C & $\mathbf{0 , 0 0}$ & 0,52 & & 0,74 \\
\hline D & $\mathbf{0 , 0 0}$ & 0,68 & 0,31 & & D & $\mathbf{0 , 0 0}$ & 0,98 & 0,74 & \\
\hline
\end{tabular}

różnice są istotne $\mathrm{z}$ p $<0,05$; podziału dokonano wg wartości miary sytuacji finansowej; pogrubione wartości to grupy istotnie różniące się od pozostałych $\mathrm{w}$ aspekcie prezentowanych relacji

Źródło: opracowanie własne na podstawie danych BDL GUS.

Rozkład miary syntetycznej sytuacji finansowej powiatów Polski Wschodniej jest przestrzennie spolaryzowany. Na sytuacje finansową wpływa charakter gospodarczy regionu, położenie względem silnych jednostek miejskich, dochody z PIT i CIT czy wydatki inwestycyjne. Wartość wskaźnika wahała się w granicach w 2010 - 0,83 do 0,62, w 2012 - 0,83 do 0,65, w 2016 - 0,81 do 0,60.

$\mathrm{W}$ aspekcie rozwoju miara syntetyczna, wskazuje na słaby poziom powiatów. Jej wartość wahała się w granicach od 0,48 do 0,83 w 2010 roku; 0,50 do 0,83 w 2012 roku; 0,48 do 0,81 w 2016 roku. Na wzrost poziomu rozwoju gospodarczego powiatów miały wpływ pozytywne zmiany w zakresie potencjału gospodarczego i infrastruktury czy sytuacji finansowej.

Wydaje się, że zastosowana metoda badań okazała się skutecznym narzędziem w analizie porównawczej powiatów Polski Wschodniej. Pozwoliła wymienić grupę determinantów wpływających na rozwój i sytuację finansową. Klasyfikacja powiatów jest użytecznym narzędziem oceny poziomu rozwoju i oceny realizowanych zadań, efektów przyjętych celów do realizacji. Wartość miary uzależniona jest od ilości i rodzaju przyjętych zmiennych do badania. 


\section{Literatura}

Adamowicz A., 2003, Kształtowanie rozwoju lokalnego, [w:] Strategie rozwoju lokalnego. Aspekty instytucjonalne, Adamowicz M. (red.), SGGW, Warszawa.

Bajorski B., Tokarski T., 2011, Przestrzenne zróżnicowanie rozwoju ekonomicznego powiatów województwa podkarpackiego, „Wiadomości Statystyczne”, nr 5.

Borodo A., 2007, Stownik finansów samorządowych, Wydawnictwo Dom Organizatora w Toruniu, Torun.

Dworakowska M., 2013, Zarzadzanie finansami miast na prawach powiatu, „ZN Uniwersytetu Szczecińskiego, nr 786 Finanse, Rynki Finansowe, Ubezpieczenia", nr 64/2.

Dylewski M., Filipiak B., Gorzałczyńska-Koczkodaj M., 2004, Analiza finansowa $w$ jednostkach samorzadu terytorialnego, Municipium, Warszawa.

Dziekański P., 2017, Diversification Synthetic Indicator for Evaluating the Financial Capacity of Local Government. The Case of Polish Voivodeships, "Acta Universitatis Agriculturae et Silviculturae Mendelianae Brunensis", nr 65(2).

Dziekanski P., 2017, Economic effectiveness of the activities of local self-government units in the light of the municipality financial resources, "Scientific bulletin of Polissia", nr 3 (11), P. 1.

Dziekański P., 2016, Spatial changes and assessment of the financial condition of local government units in the context of the income structure, Conference Proceedings International Conference on Management Trends of Management in the Contemporary Society, Mendel University in Brno.

Dziekański P., 2016, Spatial Differentiation of the Financial Condition of the Świętokrzyskie Voivodship Counties, „Barometr Regionalny”, t. 14, nr 3.

Dziekański P., 2015, Wykorzystanie wskaznika syntetycznego do oceny poziomu rozwoju samorządu na przykładzie gmin wiejskich województwa świętokrzyskiego, [w:] Determinanty rozwoju Polski. Finanse publiczne, Owsiak S. (red.), PTE, Warszawa.

Efektywność, planowanie, rozwój - jednostki samorzadu terytorialnego wobec kluczowych wyzwań strukturalnych, Instytut Sobieskiego, Warszawa 2012.

Grabiński T., Wydymus S., Zeliaś A., 1983, Metody prognozowania rozwoju społeczno-gospodarczego, PWE, Warszawa.

Heffner K., 2002, Czynniki osadnicze wplywające na potencjał rozwojowy obszarów wiejskich, [w:] Wiejskie obszary kumulacji barier rozwojowych, Kłodziński M. (red.), IRWiR PAN, Warszawa.

Jajuga K., 1984, O pewnym uogólnieniu zagadnienia klasyfikacji, „Prace Naukowe Akademii Ekonomicznej we Wrocławiu, Statystyka - Ekonometria", nr 285. Jastrzębska M., 2012, Finanse jednostek samorzadu terytorialnego, Wolters Kluwer business, Warszawa.

Kachniarz M., 2011, Bogactwo gmin - efekt gospodarności czy renty geograficznej?, "Ekonomia Economics", nr 5(17).

Klamut M. (red.), 1999, Konkurencyjność regionów, Wydawnictwo AE im. O. Langego we Wrocławiu, Wrocław. 
Kopyściański T., Rólczyński T., 2014, Analiza wskaźników opisujących sytuacje finansowa powiatów w wojezwództwie dolnośląskim w latach 2006-2012, "Studia Ekonomiczne", nr 206.

Kozłowski W., 2012, Zarzadzanie gminnymi inwestycjami infrastrukturalnymi, Difin, Warszawa.

Malina A., 2004, Wielowymiarowa analiza przestrzennego zróżnicowania struktury gospodarki Polski wedtug województw, Wydawnictwo AE w Krakowie, Kraków.

Mioduchowska-Jaroszewicz E., 2013, Metody i kierunki oceny kondycji finansowej jednostek samorządów terytorialnych, "Zeszyty Naukowe Uniwersytetu Śląskiego, nr 786, Finansowe, Ubezpieczenia", nr 64/2.

Młodak A., 2006, Analiza taksonomiczna w statystyce regionalnej, Difin, Warszawa.

Młodak A., Józefowski T., Wawrowski Ł., 2016, Zastosowanie metod taksonomicznych w estymacji wskaźników ubóstwa, „Wiadomości Statystyczne”, R. LXI, nr 2.

Orzeczenie TK z dnia 24 stycznia 1995 r. (K 5/94), [za:] J. Oniszczuk, Konstytucja RP w orzecznictwie Trybunału Konstytucyjnego, Kraków 2000.

Ossowska L., 2013, Renta położenia jako determinanta rozwoju społeczno-gospodarczego obszarów wiejskich w Polsce, Wydawnictwo UP w Poznaniu, Poznań.

Ossowska L., Poczta W., 2009, Endogenne uwarunkowania rozwoju społeczno-gospodarczego obszarów wiejskich Pomorza Środkowego, Wydawnictwo UP w Poznaniu, Poznań.

Satoła Ł., 2015, Kondycja finansowa gmin w warunkach zmiennej koniunktury gospodarczej, "Journal of Agribusiness and Rural Development", nr 1(35), s. $115-123$.

Sobczyk A., 2010, Rozwój lokalny - wybrane problemy finansowania, "Zeszyty Naukowe SGGW, Ekonomika i Organizacja Gospodarki Żywnościowej”, nr 81.

Szymla Z., 2000, Determinanty rozwoju regionalnego, Wydawnictwo Ossolineum, Wrocław-Warszawa-Kraków.

Trojak M., Tokarski T. (red.), 2013, Statystyczna analiza przestrzennego zróżnicowania rozwoju ekonomicznego i społecznego Polski, Wydawnictwo UJ, Kraków.

Wojciechowski E., 2012, Zarzadzanie w samorzadzie terytorialnym, Difin, Warszawa.

Wysocki F., 1996, Metody statystycznej analizy wielowymiarowej w rozpoznawaniu typów struktury przestrzennej rolnictwa, Roczniki AR w Poznaniu, seria: Rozprawy Naukowe, z. 266, Poznań.

Wysocki F., 2010, Metody taksonomiczne w rozpoznawaniu typów ekonomicznych rolnictwa i obszarów wiejskich, Wydawnictwo Uniwersytetu Przyrodniczego w Poznaniu, Poznań.

Zeliaś A., 2002, Uwagi na temat wyboru metody normowania zmiennych diagnostycznych, [w:] Analiza szeregów czasowych na początku XXI wieku, Kufel T., Piłatowska M. (red.), Wydawnictwo Uniwersytetu Mikołaja Kopernika, Toruń. 